Review Article

\title{
The Fate of Allogeneic Pancreatic Islets following Intraportal Transplantation: Challenges and Solutions
}

\author{
Xinyu Li, Qiang Meng, and Lei Zhang $(\mathbb{D}$ \\ Department of General Surgery, The 2nd Affiliated Hospital of Harbin Medical University, 246 Xuefu Road, Harbin, \\ 150086 Heilongjiang Province, China \\ Correspondence should be addressed to Lei Zhang; doctorzhanglei@gmail.com
}

Received 4 May 2018; Accepted 27 August 2018; Published 23 September 2018

Academic Editor: Isabella Quinti

Copyright ( 2018 Xinyu Li et al. This is an open access article distributed under the Creative Commons Attribution License, which permits unrestricted use, distribution, and reproduction in any medium, provided the original work is properly cited.

\begin{abstract}
Pancreatic islet transplantation as a therapeutic option for type 1 diabetes mellitus is gaining widespread attention because this approach can restore physiological insulin secretion, minimize the risk of hypoglycemic unawareness, and reduce the risk of death due to severe hypoglycemia. However, there are many obstacles contributing to the early mass loss of the islets and progressive islet loss in the late stages of clinical islet transplantation, including hypoxia injury, instant blood-mediated inflammatory reactions, inflammatory cytokines, immune rejection, metabolic exhaustion, and immunosuppression-related toxicity that is detrimental to the islet allograft. Here, we discuss the fate of intrahepatic islets infused through the portal vein and propose potential interventions to promote islet allograft survival and improve long-term graft function.
\end{abstract}

\section{Introduction}

Insulin deficiency caused by autoimmune injury of islet $\beta$ cells is the primary cause of type 1 diabetes mellitus (T1DM). Islet replacement therapy (insulin-secreting pancreas transplantation or islet transplantation) enables the physiological regulation of blood glucose and precise maintenance of glycemia, which is not attainable by other modern interventions, including insulin pumps and/or continuous blood glucose monitoring therapies. Compared with pancreas transplantation, islet transplantation exhibits great promise due to its safe and minimally invasive process and is a sought-after option for the treatment of T1DM.

Over the past 20 years, significant progress has been made in the management of islet cells and the outcome of clinical islet transplantation. In some leading islet transplant centers, it is possible to achieve 5-year insulin independence rates of $50-70 \%$, on a par with whole-pancreas transplantation in T1DM patients [1-5]. However, many challenges remain in clinical islet transplantation. In this review, we focused on the fate of the islets infused through the portal vein, which are subjected to multiple insults, including anoxia/ischemiareperfusion injury, instant blood-mediated inflammatory reaction (IBMIR), potent autoimmune and alloimmune rejections, metabolic exhaustion, and immunosuppression-related toxicity (Figure 1). We also propose protective strategies to circumvent these adverse events to alleviate the loss of islets and improve the long-term outcomes of transplantation.

\section{Hypoxia}

Due to their high oxygen dependence and lack of ability to scavenge free radicals, islets are particularly vulnerable to hypoxia [6]. Revascularization is imperative for long-term survival of dispersed islets in the hepatic vascular network. This process usually takes 10-24 days [7], and vascular remodeling can take up to three months [8].

Before the vessels grow into the islets, the survival of the islets primarily depends on the passive diffusion of nutrients and oxygen; thus, the larger the islet diameter, the more susceptible the central cells are to hypoxia.

Cultured islets in vitro often appear darkened in the central region when observed under an inverted microscope. This phenomenon is defined as central cell necrosis, which is often associated with reduced islet function [9]. Smaller islets are therefore favorable for transplantation and might 


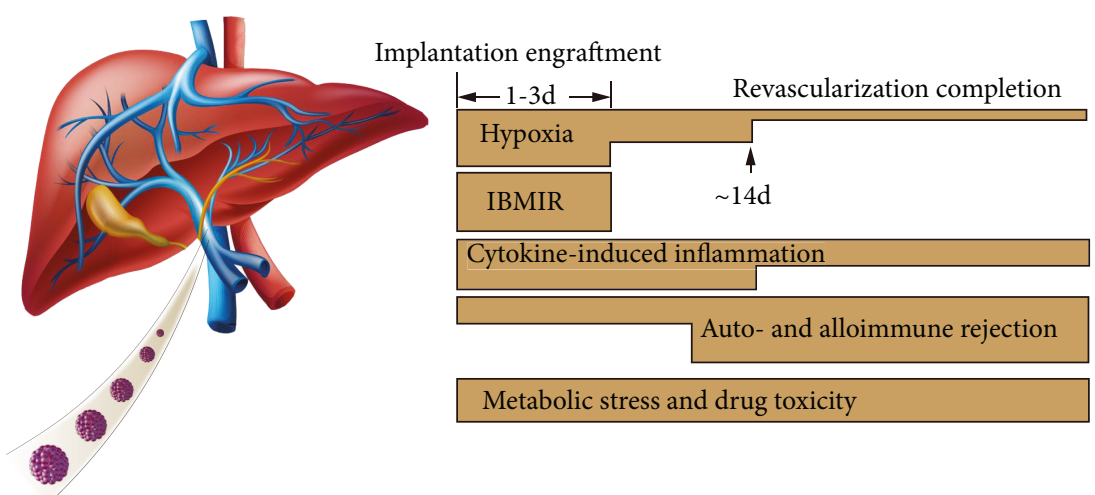

Figure 1: Time frame of detrimental factors leading to early injury and late loss of function after islet transplantation is shown. Massive tissue loss due to IBMIR early during transplantation reduces successful engraftment. Islets endure a severely hypoxic environment in the first several days and rely only on passive oxygen diffusion for survival.

lead to better graft survival [10]. Even after vascularization is complete, the vascular density, oxygen tension, and blood perfusion of the engrafted islets remain in an anoxic state compared with native islets [11-13]. Prolonged hypoxia during islet transplantation initiates a cascade of biochemical reactions causing the production of reactive oxygen species and the induction of apoptosis and necrosis via intracellular pathways [14]. Additionally, hypoxia and reperfusion of oxygen induce the release of multiple proinflammatory mediators from islets, such as high mobility group box-1, regulated upon activation of normal $\mathrm{T}$ cell expressed and secreted, tumor necrosis factor- $\alpha$ (TNF- $\alpha$ ), interleukin- $1 \beta$, interferon gamma, monocyte chemoattractant protein-1, tissue factor (TF), and macrophage inflammatory protein $1 \alpha[15,16]$, which amplifies inflammation that, in turn, impairs islet survival.

2.1. Strategies to Overcome Islet Hypoxia. A variety of methods have been proposed to promote the survival and improve the function of islets in an anoxic environment. These methods can be divided into two categories: (1) protection of islets from hypoxic injury and (2) increased oxygen supply to islets to prevent hypoxia.

Some studies have shown that gene modification can endow islets with resistance to hypoxia by inhibiting apoptotic triggers. For example, heme oxygenase-1 [17, 18], A20 [19-21], B cell lymphoma 2, and X-linked inhibitor of apoptosis [22] have been identified to prevent/alleviate islet apoptosis and improve islet survival under in vitro and in vivo experimental conditions but remain to be validated in clinical studies.

Detrimental oxidative products released by hypoxia, such as inducible nitric oxide synthase and reactive oxygen species, promote the expression of proapoptotic genes (i.e., Fas and $\mathrm{Bax}$ ), resulting in rapid apoptosis or necrosis of $\beta$ cells [23]. Treatment of islet grafts with potent antioxidants can mitigate oxidative stress. Enicostemma littorale methanol extract can protect islets from oxidative stress-induced cell death in vitro [24]. A redox-active metalloporphyrin, BMX-001, was shown to enhance islet viability, reduce apoptosis in vitro, and improve marginal islet mass engraftment in diabetic mouse models [25]. Controlling oxidative stress may improve islet survival.

The second category includes accelerating the islet vascularization process posttransplantation and increasing oxygen content at the transplant site. High levels of vascular endothelial growth factor (VEGF) expression in islets and vascular endothelial cells contribute to neovascularization $[8,26]$. The addition of VEGF to islet grafts has both positive and negative effects, as VEGF also expedites and amplifies inflammation, which is harmful to the survival of the islets. Lee et al. reported that VEGF-transfected islets could enhance islet vascularization and graft function in STZ-induced diabetic mice [27]. Hepatocyte growth factor, fibroblast growth factor, epidermal growth factor, and biomaterials can also favor isolated islet angiogenesis [28]. Uematsu et al. used a novel scaffold, recombinant peptide to optimize prevascularization procedures to augment subcutaneous islet function in mice [29]. A 3D-printed vascularized device has been invented and has enabled the long-term survival of human islets subcutaneously in immune-deficient mice [10]. Oxygen feeding to the transplanted islet is an intuitive means to overcome hypoxia. In this case, the islets are usually stored in a bioartificial pancreas device and the de novo generated oxygen is produced by electrochemistry [30]/photosynthesis [31] or exogenous oxygen and is delivered into the device for islet use. Hyperbaric oxygen therapy has been used for islet transplantation in mice [32-35] and for autologous stem cell infusion in patients with type 2 diabetes mellitus [36], providing therapeutic potential for human islet transplantation. Most of the abovementioned techniques are still at different stages of preclinical trials.

\section{IBMIR}

Thus far, intraportal islet infusion remains the optimal approach for clinical transplantation. A large number of islets are innately destroyed by an event termed IBMIR on contact with the recipient's blood. It is estimated that approximately $60-70 \%$ of islets are lost prior to hepatic engraftment, which is the main cause of "primary nonfunction" and the 


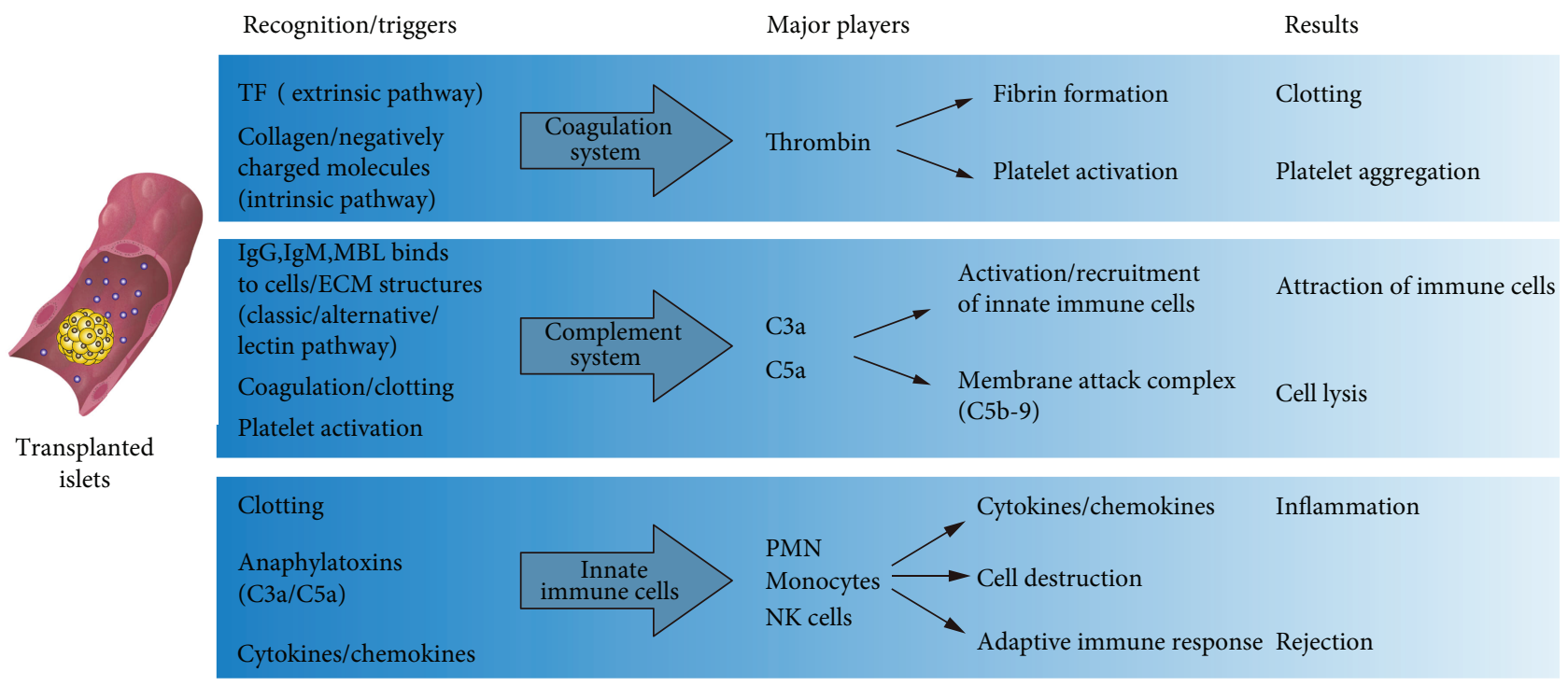

FIGURE 2: Coagulation, complement, and immune cells interact to orchestrate IBMIR, the primary cause of early massive loss of transplanted islets. Figure modified from Digital Comprehensive Summaries of Uppsala Dissertations from the Faculty of Medicine 1030.

need for 2-3 pancreas donors to achieve euglycemia in the initial period following transplantation [37, 38].

The thrombotic/inflammatory reaction is a cascade reaction that start with the coagulation and complement system activation, activated platelet adhesion to the islet surface, and abundant leukocyte infiltration into the islets with structure integrity disruption $[39,40]$.

The functional impairment and death of pancreatic islets by IBMIR is usually ascribed to multiple pathological effects. First, the infiltrating cells (neutrophils and macrophages) are directly cytotoxic to the islet cells $[41,42]$. Second, inflammatory cytokines lead to apoptosis and necrosis of the islet cells [43]. Finally, IBMIR potentiates and amplifies the subsequent cell-mediated immune response (Figure 2) [42, 44, 45].

\subsection{Strategies for Alleviating IBMIR. According to the reaction} characteristics, coagulation, complement activation, and inflammatory processes can be taken as individual and/or combined intervention targets. Potential approaches to relieve stress and protect islets can be achieved through pretreatment of islets in vitro and systematically administered with anticoagulants, complement inhibitors, anti-inflammatory reagents, or islet surface engineering (Table 1). We will discuss these measures briefly below.

Both pretreatment and gene modification are capable of weakening the procoagulant and proinflammatory status of pancreatic islets to minimize the deleterious outcomes of IBMIR. TF serves as the main trigger of IBMIR and can inhibit blood coagulation by reducing the expression level of TF. Islets pretreated with nicotinamide in vitro can downregulate TF, monocyte chemoattractant protein-1, and other inflammatory cytokines dramatically [46]. Due to the extensive nature of events associated with IBMIR, multiple genetic modifications may be required to provide adequate graft protection.

The main purpose of gene manipulation in human islets in vitro is to introduce antiapoptotic genes and antioxidant genes to enhance the resistance of transplanted islets to inflammation-induced injury, which constitutes a major component of IBMIR. For example, B cell lymphoma 2 -transfected human islets were obviously protected from cytokine-induced dysfunction in vitro [47].

Multiple genes are modified simultaneously in an individual islet to resist the harmful effects of the coagulation and complement system, and the use of a transgenic donor is the best solution. In this respect, pig islet xenotransplantation presents remarkable advantages and significant progress has been made. Pigs without TF and pigs expressing a human "antithrombotic" or "anticoagulant" gene, such as thrombomodulin, TF pathway inhibitor, or $\mathrm{CD} 39$, are available to minimize IBMIR and coagulation dysfunction [48].

Systematic application of heparin or low-molecularweight dextran sulfate and soluble complement receptor-1 can improve islet survival by downregulating allogeneic IBMIR in experimental settings but remains to be validated in clinical studies [38, 49-51]. Controlling the inflammatory response can also alleviate IBMIR. Gala-Lopez et al. have shown that double blockade of interleukin- $1 \beta$ and TNF- $\alpha$ can significantly improve the efficiency of clinical islet transplantation, particularly in single-donor islet transplantation [52]. Recent studies demonstrated that both the CXC chemokine receptors $1 / 2$ inhibitor reparixin [53] and serine protease inhibitor $\alpha 1$-antitrypsin [54] improved intrahepatic islet transplantation outcomes in mice and human trials, further confirming the efficacy of anti-inflammatory strategies, e.g., peritransplantation, that have been an essential component of current clinical islet transplantation. Surface engineered islets have been proven to ameliorate islet survival after islet transplantation by portal vein. For instance, heparin-coated islets attenuate the IBMIR and lead to more islets survived both in vitro loop model and in vivo pig model mimicking allogeneic intraportal islet transplantation [55]. Urokinase-, thrombomodulin-, and soluble complement receptor 1-coated islets can attenuate coagulation and 
TABLE 1: Selected treatment options for islet graft and islet transplant recipient on targets associated with IBMIR.

\begin{tabular}{|c|c|c|c|}
\hline \multicolumn{2}{|c|}{ Donor (in vitro pretreatment) } & \multicolumn{2}{|c|}{ Recipient (in vivo treatment) } \\
\hline Agent & Mechanism & Agent & Mechanism \\
\hline \multicolumn{4}{|l|}{ Coagulation } \\
\hline Anti-TF mAb & Anti-TF & Anti-TF mAb & Anti-TF \\
\hline Nicotinamide & $\begin{array}{c}\text { Downregulation of TF expression on } \\
\text { isolated islets }\end{array}$ & Heparin & Anticoagulation \\
\hline \multirow{6}{*}{$\begin{array}{l}\text { Surface engineering } \\
\text { of islets } \\
\text { (i) Heparin coating } \\
\text { (ii) PEG coating } \\
\text { (iii) Composite } \\
\text { islet-endothelial cell } \\
\text { graft }\end{array}$} & \multirow{6}{*}{$\begin{array}{l}\text { Covering of islets to prevent direct } \\
\text { exposure to blood }\end{array}$} & LMW-DS & Anticoagulation \\
\hline & & Melagatran & $\begin{array}{l}\text { Anticoagulation via thrombin } \\
\text { inhibition }\end{array}$ \\
\hline & & Nacystelyn & $\begin{array}{l}\text { Anticoagulation, anti-inflammatory, } \\
\text { \& antioxidant effects }\end{array}$ \\
\hline & & Activated protein $C$ & $\begin{array}{c}\text { Anticoagulation, fribrinolysis, NF- } \kappa \mathrm{B} \\
\text { inhibition }\end{array}$ \\
\hline & & Thrombomodulin & $\begin{array}{c}\text { Anticoagulation via thrombin } \\
\text { inhibition }\end{array}$ \\
\hline & & Glycoprotein IIb/IIIa inhibitors & $\begin{array}{l}\text { Inhibiting fibrinogen binding to the } \\
\text { receptors to prevent platelet activation } \\
\text { and aggregates }\end{array}$ \\
\hline \multirow{6}{*}{$\alpha$-Antitrypsin } & \multirow{6}{*}{ Complement inhibition } & Complement & \\
\hline & & LMW-DS & Complement inhibition \\
\hline & & Compstatin & Complement inhibition \\
\hline & & Cobra venom factor & Depleting the complements \\
\hline & & sCR1 (TP10) & $\begin{array}{l}\text { Negative regulator of the complement } \\
\text { cascade that inhibits both the classic } \\
\text { and alternative pathways }\end{array}$ \\
\hline & & C5a inhibitory peptide (C5aIP) & $\begin{array}{l}\text { Blocks the deleterious effects of C5a to } \\
\text { reduce complement activation, the } \\
\text { chemotactic effect, and inflammatory } \\
\text { reactions }\end{array}$ \\
\hline
\end{tabular}

\begin{tabular}{|c|c|c|c|}
\hline \multicolumn{4}{|c|}{ Proinflammatory mediators } \\
\hline$\alpha$-Antitrypsin & Blockade of PIC production & $\alpha$-Antitrypsin & Blockade of PIC production \\
\hline Antioxidant & $\begin{array}{l}\text { Scavenging of reactive oxygen species } \\
\text { produced the isolation process }\end{array}$ & 15-DSG & $\begin{array}{c}\text { Blockade of PIC production via NF- } \kappa \mathrm{B} \\
\text { inhibition }\end{array}$ \\
\hline Statins & $\begin{array}{l}\text { Protection against ischemia- } \\
\text { reperfusion injury } \\
\text { Inhibition of proapoptotic pathways }\end{array}$ & Anti-TNF- $\alpha$ mAb & $\begin{array}{l}\text { Binding to TNF- } \alpha \text { prevents the } \\
\text { stimulation of its receptor }\end{array}$ \\
\hline $\begin{array}{l}\text { Heme oxygenase- } 1 \\
\text { induction }\end{array}$ & $\begin{array}{l}\text { Anti-inflammatory effects via p38 } \\
\text { MAPK-dependent pathway }\end{array}$ & IL-1 receptor antagonist & $\begin{array}{l}\text { Prevention of IL- } 1 \beta \text { from binding to the } \\
\text { IL- } 1 \text { receptor }\end{array}$ \\
\hline A-20 induction & $\begin{array}{l}\text { Anti-inflammatory effects via NF- } \kappa \mathrm{B} \\
\text { inhibition potent antiapoptotic gene }\end{array}$ & Reparixin & $\begin{array}{l}\text { Binding to CXCR } 1 / 2 \text { to block the } \\
\text { CXCL8/IL-8 axis }\end{array}$ \\
\hline Active vitamin $\mathrm{D}$ & $\begin{array}{l}\text { Anti-inflammatory effects by induction } \\
\text { of protective gene expression }\end{array}$ & zVAD-FMK & $\begin{array}{l}\text { Pan-caspase inhibitor that suppresses } \\
\text { cell apoptosis }\end{array}$ \\
\hline Withaferin A & $\begin{array}{c}\text { Anti-inflammatory effects via NF- } \kappa \mathrm{B} \\
\text { inhibition }\end{array}$ & IDN-6556 & $\begin{array}{l}\text { Pan-caspase inhibitor that suppresses } \\
\text { cell apoptosis }\end{array}$ \\
\hline & $\begin{array}{l}\text { Anti-inflammatory effects by reduction } \\
\text { of PIC production }\end{array}$ & JNK inhibitor & $\begin{array}{l}\text { Anti-inflammatory effects by reduction } \\
\text { of PIC production } \\
\text { Antiapoptotic effects via JNK inhibition }\end{array}$ \\
\hline JNK inhibitor & $\begin{array}{c}\text { Antiapoptotic effects via JNK } \\
\text { inhibition }\end{array}$ & $\begin{array}{l}\text { GLP-1 R agonist } \\
\text { (i) Exenatide (short half-life) } \\
\text { (ii) Liraglutide (long half-life) }\end{array}$ & $\begin{array}{c}\text { Reducing apoptosis due to oxidative } \\
\text { stress \& enhancing insulin release } \\
\text { Anti-inflammatory \& antioxidative } \\
\text { properties }\end{array}$ \\
\hline
\end{tabular}

IBMIR = instant blood-mediated inflammatory reaction; PIC = proinflammatory cytokines; TF = tissue factor; LMW-DS = low-molecular-weight dextran sulfate; TNF- $\alpha=$ tumor necrosis factor- $\alpha$; sCR1 = soluble complement receptor type 1; 15-DSG=15-deoxyspergualin; GLP-1R = glucagon-like peptide-1 receptor; $\mathrm{IL}=$ interleukin; $\mathrm{JNK}=\mathrm{c}$-Jun $\mathrm{N}$-terminal kinase; $\mathrm{MAPK}=$ mitogen-activated protein kinase; $\mathrm{CXCL}=\mathrm{CXC}$ chemokine ligand; $\mathrm{CXCR}=\mathrm{CXC}$ chemokine receptor. 
complement activation when exposed to blood [56-58]. Human aortic endothelial cells conjugated to the islet surface significantly reduce all of the deleterious reactions of the IBMIR [59]. Although these techniques exhibit the greatest potential for islet preservation under experimental conditions, further investigation and evaluation are needed in clinical therapy.

\section{Autoimmunity Recurrence and Alloimmunity}

The islet allografts implanted in patients with T1DM are subjected to at least two separate categories of immune responses: (1) autoimmune $\mathrm{T}$ cell response and (2) conventional host antigraft immune response.

4.1. Autoimmunity. The pathogenesis of T1DM similarly affects the newly implanted islet grafts. The silent original autoreactive $\mathrm{T}$ cells with immune memory are reawakened by identical antigen reexposure after islet transplantation and trigger an attack on the graft, which could be supported by the fact that syngeneic $\beta$ cells were damaged in autoimmune diabetic recipients [60]. The precise role of autoantibodies against $\beta$ cell autoantigens, such as insulin-specific autoantibodies, glutamic acid decarboxylase, insulinoma antigen, and zinc transporter- 8 , in the pathogenesis of type 1 diabetes is unclear but of great significance to the prediction and diagnosis of T1DM [61]. People with 2 or more autoantibodies are more likely to develop T1DM than those with a single autoantibody [62]. However, the predictive ability of these antibodies in patients with islet transplantation remains controversial. Early studies of the immune response after islet transplantation have shown no correlation between preexisting autoreactive antibodies and graft dysfunction $[63,64]$, but later evidence demonstrated that patients with preformed autoantibodies have earlier islet graft loss than recipients without antibodies [65]. In contrast, autoreactive $\mathrm{T}$ cells (including $\mathrm{CD} 4$ and $\mathrm{CD} 8 \mathrm{~T}$ cells) represent crucial players in the destruction of $\beta$ cells and are the active intervention targets for therapy.

4.2. Alloimmunity. Alloimmunity is another major cause of transplanted islet destruction. Genetic diversity between the donor and the recipient determines the occurrence of immune response, which focuses primarily on human leukocyte antigen molecules in humans and major histocompatibility complex (MHC) in mice. T cell-mediated rejection constitutes the most important component in islet allotransplantation. The difference in human leukocyte antigen-1 antigens is the target of recipient $\mathrm{CD} 8 \mathrm{~T}$ cells, and the difference in MHC-2 antigens is the target of recipient CD4 T cells [66].

Whether the antigen is presented directly or indirectly, the activation of $\mathrm{T}$ cells is a critical step in rejection and requires the coordination of three signal systems (Figure 3(a)). That is, the first signal (peptide-MHC complex on the antigen-presenting cells), the second signal (costimulatory molecules such as B7-CD28 and CD40-CD154), and the third signal (cytokines) further amplify the proliferation of T cells [67]. The ultimate biological effect is the recruitment of immune cells to the grafts with function loss.

Patients undergoing allogeneic transplants can have humoral immunity, an antibody-mediated immune response, involved in the rejection process. Alloreactive antibodies are mainly directed towards MHC class I and MHC class II molecules. They include nonspecific antibodies called panelreactive antibodies (PRAs) and donor-specific antibodies (DSAs). Both are recognized as predictive prognostic markers related to islet transplantation outcomes despite paradoxical and uncertain roles. Early studies have shown that pretransplant allogenic antibodies measured as PRA are a negative predictor of islet transplantation outcomes [68]. Pretransplantation PRA $>15 \%$ is associated with increased risk of C-peptide loss after islet transplantation [63, 69]. Islet transplantation outcomes in sensitized patients are often worse than those in nonsensitized patients [69]. Later, evidence did not support such a correlation between preformed PRA and islet function posttransplantation [70]. In contrast, there exists evidence that posttransplant-positive PRA levels and de novo DSA cannot predict islet transplantation outcomes [71].

\subsection{Strategies for the Prevention of Auto- and Alloimmune} Rejections. It is clear that both autoimmunity and alloimmunity contribute to the loss of islet function, which can occur separately or simultaneously in a single transplant process. Although remarkable progress in understanding the immune response mechanisms have occurred, it remains an important challenge to circumvent these response mechanisms in clinical settings. To date, suppression of $\mathrm{T}$ cells with globally immunosuppressive agents is the most widespread and practical approach (Table 2), as both production of antibodies and proliferation of $\mathrm{B}$ cells required the help of $\mathrm{T}$ cells. Inhibition of $\mathrm{T}$ cells, to some extent, can decrease the humoral immunity, although not completely. We will focus on cellular immunity in the following section.

Various immunosuppressive strategies have been examined in preclinical mouse models and are applied in the clinical setting; these therapies are divided into the induction and the maintenance of immunosuppression (Figure 3(b)). The principle of induced immunosuppression is to use preemptive means to maximize the consumption of $\mathrm{T}$ cells or inhibit the activation of $\mathrm{T}$ cells, including anti-CD3, antithymocyte globulin, or interleukin 2 receptor blockade prior to islet transplantation. Potent induction therapy with anti-CD3 $\mathrm{Ab}$ or T cell-depleting antibodies plus TNF- $\alpha$ inhibition is significantly associated with 5 -year insulin independence of approximately $50 \%$ in islet transplant alone, comparable to outcomes in pancreas transplant alone, regardless of the choice of maintenance immunosuppression [1]. The maintenance of immunosuppression is more dependent on lifelong inhibition of $\mathrm{T}$ cell activation and proliferation, including tacrolimus, mTOR inhibitors, and mycophenolate mofetil [72], with the obvious drawbacks that most of these drugs exhibit liver and kidney toxicity and have direct toxicity to $\beta$ cells. Of particular interest, costimulatory blockade represents a potential therapy that promotes immune tolerance, which has been demonstrated by several groups. For 


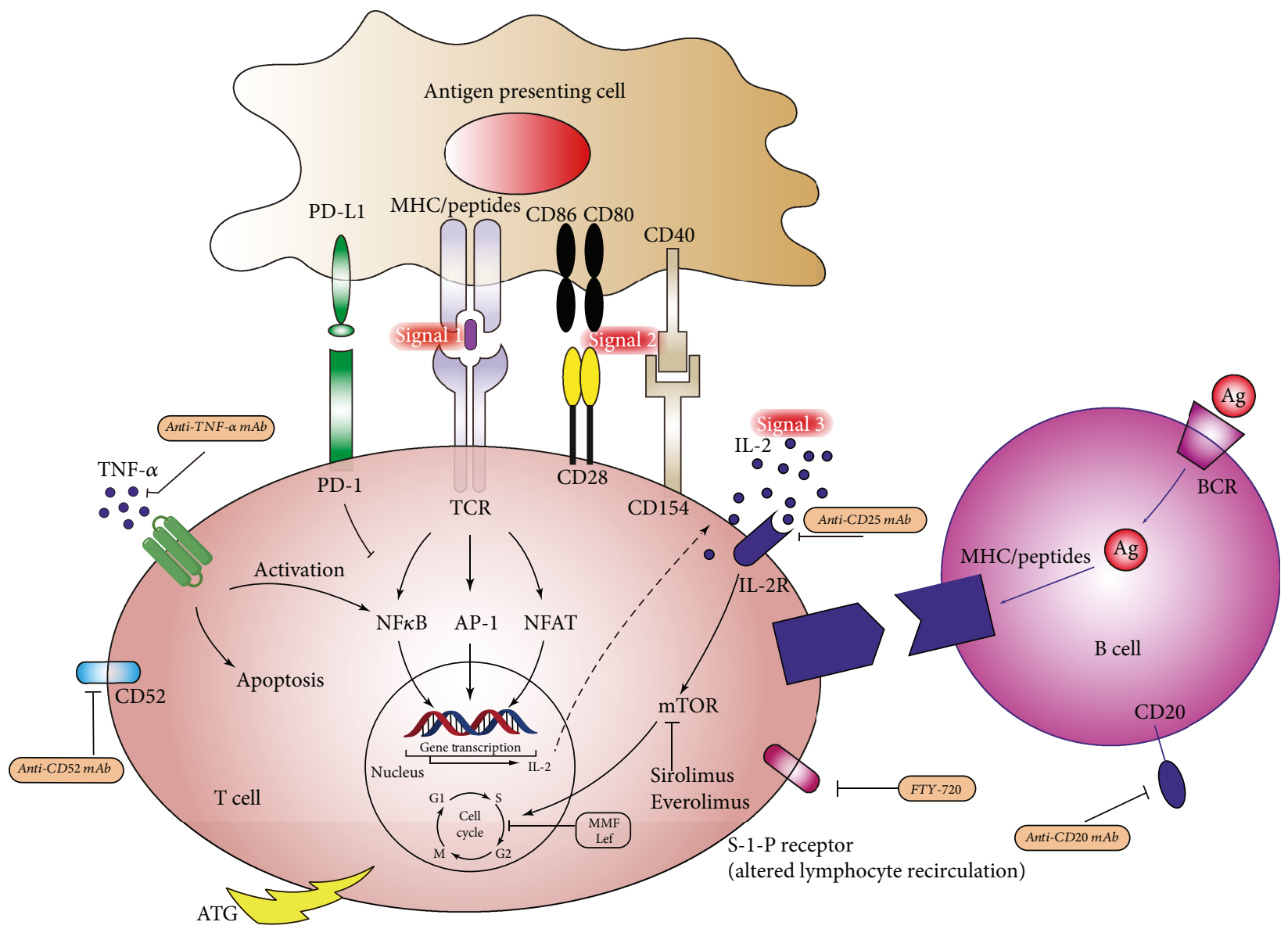

(a)

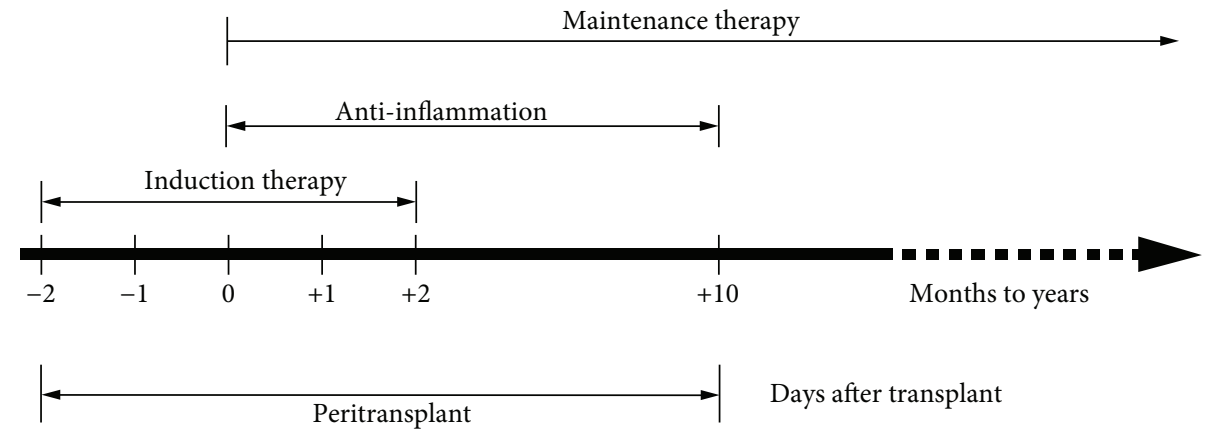

(b)

Figure 3: (a) The three-signal pattern of $\mathrm{T}$ lymphocytes activated in islet allotransplantation. Action targets and brief mechanisms are displayed. (b) Current immunosuppressive protocol commonly used in clinical islet transplantation associated with improved long-term islet allograft survival.

instance, short-term use of anti-CD154 monoclonal antibodies can lead to allograft tolerance when Balb/c islets are transplanted into STZ-treated C57BL/6 mice [73]. Moreover, anti-CD154 antibody plus other interventions, especially LFA-1 blockade, is highly effective [74]. Anti-CD154 antibody and LFA-1-induced tolerance in CD4 T-lymphocyte subsets can transfer to multiple islet transplant recipients [74]. Unfortunately, thrombotic events caused by antiCD154 antibody hinder its clinical use. Newly developed anti-CD40 mAbs such as Chi220, ASKP40 (4D11), 3A8, and 2C10 may be equipotent but safe. Chi220 has been shown to extend allogenic islet survival time to more than 200 days in combination with belatacept (CTLA4-Ig) in MHC-mismatched rhesus macaques [75]. ASKP40 exhibits promise in retarding renal allograft rejection and antibody production in NHPs [76]. Badell et al. reported that $3 \mathrm{~A} 8$ plus CTLA4Ig prevented DSA formation and potentially confers long-term islet allograft survival in alloislet nonhuman primate models [77]. NHP experiments with 2C10 also confirmed prolonged islet survival, with median graft survival 
TABLE 2: Selected immunosuppressive and anti-inflammatory agents used in islet transplantation.

\begin{tabular}{|c|c|c|c|}
\hline Generic name & Trade name & Mechanism of action & Reference \\
\hline \multicolumn{4}{|c|}{ Induction (depletion of $T$ cell or inhibition of $T$ cell activation) } \\
\hline Antithymocyte globulin (ATG) & Thymoglobulin & Polyclonal antibody, profound $\mathrm{T}$ cell depletion & {$[100]$} \\
\hline Muromonab-CD3 & Orthoclone OKT3 & Anti-CD3 mAb, T cell depletion & {$[101]$} \\
\hline Alemtuzumab & $\begin{array}{l}\text { Campath } \\
\text { Lemtrada }\end{array}$ & Anti-CD52 mAb, T cell depletion & {$[102]$} \\
\hline Basiliximab & Simulect & Anti-CD25 mAb IL-2 receptor antagonist & [103] \\
\hline Daclizumab & Zenapax & Anti-CD25 mAb IL-2 receptor antagonist & {$[104]$} \\
\hline \multicolumn{4}{|c|}{ Maintenance (inhibition of $T$ cell activation and proliferation) } \\
\hline Azathioprine & Imurel & $\begin{array}{c}\text { Purine synthesis inhibitor } \\
\text { Inhibition of } \mathrm{T} / \mathrm{B} \text { cell proliferation }\end{array}$ & [105] \\
\hline Cyclosporine & $\begin{array}{l}\text { Sandimmune } \\
\text { Neoral }\end{array}$ & $\begin{array}{l}\text { Calcineurin inhibitor } \\
\text { Inhibition of } \mathrm{T} \text { cell proliferation }\end{array}$ & [106] \\
\hline Tacrolimus & $\begin{array}{c}\text { Prograf } \\
\text { Advagraf }\end{array}$ & $\begin{array}{l}\text { Calcineurin inhibitor } \\
\text { Inhibition of } \mathrm{T} \text { cell proliferation }\end{array}$ & {$[94]$} \\
\hline Mycophenolate mofetil (MMF) & CellCept & $\begin{array}{l}\text { Purine synthesis inhibitor } \\
\text { Inhibition of } \mathrm{T} / \mathrm{B} \text { cell proliferation }\end{array}$ & {$[107]$} \\
\hline Sirolimus & Rapamune & mTOR inhibitor, inhibits T/B cell proliferation & {$[108]$} \\
\hline Everolimus & Zortress/Certican & mTOR inhibitor & [106] \\
\hline Etanercept & Enbrel & TNF- $\alpha$ inhibitor & [106] \\
\hline Anti-CD154-mAb & & Blockage of CD40/CD154 T cell costimulation & [109] \\
\hline Abatacept (CTLA4-Ig) & Orencia (1st generation) & Blockage of B7/CD28 T cell costimulation & [110] \\
\hline Belatacept (CTLA4-Ig) & Nulojix (2nd generation) & Blockage of B7/CD28 T cell costimulation & [111] \\
\hline Leflunomide & $\begin{array}{l}\text { Arava } \\
\text { Lunava }\end{array}$ & $\begin{array}{l}\text { Pyrimidine synthesis inhibitor, blockage of the } \\
\text { proliferation of T/B cells }\end{array}$ & {$[112]$} \\
\hline \multicolumn{4}{|c|}{ Anti-inflammation } \\
\hline Adalimumab & Humira & Anti-TNF $\alpha-\mathrm{mAb}$ (human) & [113] \\
\hline Infliximab & Remicade & Anti-TNF $\alpha$-mAb (chimeric human-mouse) & [114] \\
\hline Etanercept & Enbrel & Soluble TNF receptor fusion protein & [106] \\
\hline Anakinra & Kineret & IL- $1 \beta$ receptor antagonist & [115] \\
\hline A1AT (alpha-1 antitrypsin) & & Reduction in inflammatory cytokines & {$[54]$} \\
\hline SP600125 (JNK inhibitor) & & Inhibition of the production of PIC & [116] \\
\hline
\end{tabular}

$\mathrm{PIC}=$ proinflammatory cytokines; $\mathrm{mAb}=$ monoclonal antibody; $\mathrm{TNF}=$ tumor necrosis factor; $\mathrm{IL}=$ interleukin.

time for animals receiving $2 \mathrm{C} 10$ of 280 days compared to 8 days for control animals [78]. The abovementioned results suggest the possibility that blockade of B7/CD28 signals and anti-CD40 $\mathrm{mAb}$ constitutes a promising immunosuppressive strategy to circumvent inadvertent thrombotic events caused by anti-CD154. Additional investigations are required to validate these findings in clinical human islet transplantation. Another option is to promote the expression of T cell inhibitory receptors on the islet. An example of such an approach is that surface engineered $\mathrm{Ba} / \mathrm{c}$ islet grafts with the expression of FasL in conjunction with rapamycin treatment led to tolerance that was maintained by $\mathrm{CD} 4(+) \mathrm{CD} 25(+)$ Foxp3(+) regulatory $\mathrm{T}$ cells (Tregs) in $100 \%$ of C57BL/6 recipients [79]. However, there exist contrary claims that the expression of the Fas ligand does not provide protection for grafts but instead exacerbates transplanted islet rejection $[80,81]$ and native islet autoimmune destruction [82]. In this way, its role in islet transplantation remains controversial [83]. Another example is a recently published report showing that enforced PDL-1 and CTLA-4 expression significantly prevented the development of autoimmune diabetes and delayed the rejection of the MHC-matched alloislet in STZ-induced diabetic mice $>120$ days (from Balb/c to DBA2), providing a potential strategy for immunosuppression-free islet transplantation [84].

Whether autoimmunity or alloimmunity represents a greater obstacle to islet transplantation success remains an elusive mystery. In clinical islet transplantation, the success of the Edmonton protocol was at least partly attributable to combined immunosuppressive regimens simultaneously blocking both auto- and alloimmune responses [85]. Other methods, including the use of biomaterials to encapsulate the islet, the infusion of donor bone marrow stem cells into recipients to produce hematopoietic chimeras [86], inducing Treg expansion in vitro and in vivo to alter the immune balance of Th1/Th2 [87], and combined infusion of donor mesenchymal stem cells [88] to enhance transplant efficacy may represent a path to induce immune tolerance or host nonresponse in autoimmune and allogeneic situations that, although experimental, is highly desirable. 


\section{Metabolic Exhaustion and Drug Toxicity}

After the initial loss of a large number of islets, the residual islets may suffer progressive dysfunction. It is unclear whether the late progressive loss of function is due to immune factors or physical exhaustion.

However, for recipients undergoing autologous pancreatic islet transplantation following total resection of the pancreas, the fact that some recipients develop diabetes over time after achieving blood sugar homeostasis points to the possibility that the chronic islet dysfunction is likely due to physiological exhaustion rather than immune factors, especially in hosts harboring a marginal islet mass [89-91].

The metabolism of $\beta$ cells is exceptionally high, constantly producing insulin-secreting granules. The fewer islets available for insulin production, the greater the metabolic pressure on each individual islet is, making the originally marginal islet grafts more dangerous. In addition, a major concern is the regeneration of transplanted islets. There is @little experimental data available to demonstrate how the islets change after transplantation. Whether $\beta$ cells are regenerated from existing $\beta$ cells or transdifferentiation by alpha cells or derived from islet intrinsic stem cells remains an open question. In any case, the isolated islets are deprived of nutrients and support from the surrounding cells and lose their primordial environment (the islets are scattered in the pancreas with surrounding exocrine tissue), which is detrimental to the regeneration and resistance of $\beta$ cells and may explain why islet grafts are more vulnerable than the pancreas after transplantation.

Antirejection drugs can effectively suppress the immune response to the alloantigen but also increase the risk of lifethreatening infections or malignant tumors. Furthermore, most immunosuppressive drugs, such as tacrolimus and mycophenolate mofetil, are detrimental to $\beta$ cells, with direct toxicity, inhibition of insulin secretion, or the proliferation of $\beta$ cells [92-95]. Thus, chronic use of these drugs will have negative impacts on grafts. Islet transplants can be deemed to be a "true cure" for diabetes only if no immunosuppressive drugs are applied.

With respect to reducing the metabolic load of islets, promoting the regeneration of $\beta$ cells, reducing apoptosis, and improving the function of islets will be beneficial to the long-term survival of islets [96-99]. For drug-related toxicity, the development of new immunosuppressive drugs with less toxicity or the establishment of specific immune tolerance or immunomodulatory therapy may change the future treatment pattern in transplantation.

\section{Concluding Remarks}

Although insulin regimen, continuous insulin infusion, and strict blood glucose monitoring have made great progress in the treatment of diabetes mellitus, it remains difficult to achieve physiologically precise regulation of blood glucose. The replacement of permanently destroyed $\beta$ cells with islet transplantation is the most logical treatment for T1DM and has proven to be very beneficial to patients. Islet transplantation can prevent severe hypoglycemia, improve haemoglobin
A1C, prevent/reverse complications, and in many cases even achieve sustained periods of insulin independence. However, the prolonged use of immunosuppressive drugs increases the risk of infection, hepatorenal toxicity, and tumorigenesis, making the treatment less attractive and limiting it to patients with severe blood sugar instability in whom other therapies have failed. Successful islet allograft via the portal vein is hampered by limited islet survival after transplantation resulting from persistent anoxia, innate immunity attacks through IBMIR, recurrent autoimmune destruction or alloimmune rejection, sustained metabolic pressure, and drug toxicity. Optimizing islet revascularization with better control of angiogenesis, inhibiting inflammation, reducing oxidative stress, and promoting the regeneration of islet $\beta$ cells can further improve the outcomes of islet survival. If these problems are properly addressed, hurdle limiting the wider use of islet transplantation in T1DM and partial type 2 diabetes mellitus will be the insufficiency of islet allograft donors.

The search for alternative sources of islets is therefore necessary. Efforts to improve islets from xenogeneic sources are ongoing, and remarkable progress has been made in the science and application of pluripotent stem cells, which are now in the early stages of clinical trials. New approaches such as the induction of specific immune tolerance and immune regulation with Treg infusion, mesenchymal stem cell cotransplantation, and innovative biological materials to protect islets from the immune system provide one feasible possibility for this therapy. The combination of genetically engineered porcine islets or pluripotent stem cells with immune isolation can solve both the organ shortage and immune rejection problems. Although the task remains challenging, success is possible. The ultimate goal of all attempts is to advance islet transplantation from glycemic control to a truly complete cure.
Abbreviations
T1DM: Type 1 diabetes mellitus
IBMIR: Instant blood-mediated inflammatory reaction
IL- $1 \beta$ : Interleukin- $1 \beta$
TNF- $\alpha$ : Tumor necrosis factor- $\alpha$
TF: $\quad$ Tissue factor
VEGF: Vascular endothelial growth factor
MHC: Major histocompatibility complex
PRA: Panel-reactive antibody
DSA: Donor-specific antibody.

\section{Conflicts of Interest}

The authors have no conflicts of interest to declare.

\section{Acknowledgments}

This work was supported by the National Natural Science Foundation of China (81571553). 


\section{Supplementary Materials}

In the process of clinical islet allotransplantation, the transfused islet grafts through portal vein into the liver are subjected to multiple insults from the host, including the early massive islet loss due to hypoxia, instant blood-mediated inflammatory reactions, inflammatory cytokine injury, and late islet failure due to immune response, metabolic stress, and/or the chronic toxicity of the immunosuppressive drugs. (Supplementary Materials)

\section{References}

[1] M. D. Bellin, F. B. Barton, A. Heitman et al., "Potent induction immunotherapy promotes long-term insulin independence after islet transplantation in type 1 diabetes," American Journal of Transplantation, vol. 12, no. 6, pp. 1576-1583, 2012.

[2] S. Lablanche, S. Borot, A. Wojtusciszyn et al., "Five-year metabolic, functional, and safety results of patients with type 1 diabetes transplanted with allogenic islets within the SwissFrench GRAGIL Network," Diabetes Care, vol. 38, no. 9, pp. 1714-1722, 2015.

[3] M. C. Vantyghem, F. Defrance, D. Quintin et al., "Treating diabetes with islet transplantation: lessons from the past decade in Lille," Diabetes \& Metabolism, vol. 40, no. 2, pp. 108-119, 2014.

[4] M. Qi, K. Kinzer, K. K. Danielson et al., "Five-year follow-up of patients with type 1 diabetes transplanted with allogeneic islets: the UIC experience," Acta Diabetologica, vol. 51, no. 5, pp. 833-843, 2014.

[5] A. R. Pepper, B. Gala-Lopez, O. Ziff, and A. M. J. Shapiro, "Current status of clinical islet transplantation," World Journal of Transplantation, vol. 3, no. 4, pp. 48-53, 2013.

[6] R. A. Simmons, "Developmental origins of diabetes: the role of oxidative stress," Best Practice \& Research Clinical Endocrinology \& Metabolism, vol. 26, no. 5, pp. 701-708, 2012.

[7] M. D. Menger, J. Yamauchi, and B. Vollmar, "Revascularization and microcirculation of freely grafted islets of Langerhans," World Journal of Surgery, vol. 25, no. 4, pp. 509-515, 2001.

[8] J. A. Emamaullee and A. M. James Shapiro, "Factors influencing the loss of $\beta$-cell mass in islet transplantation," Cell Transplantation, vol. 16, no. 1, pp. 1-8, 2007.

[9] H. Komatsu, C. Cook, C. H. Wang et al., "Oxygen environment and islet size are the primary limiting factors of isolated pancreatic islet survival," PLoS One, vol. 12 , no. 8, article e0183780, 2017.

[10] S. Pathak, S. Regmi, B. Gupta et al., "Engineered islet cell clusters transplanted into subcutaneous space are superior to pancreatic islets in diabetes," The FASEB Journal, vol. 31, no. 11, pp. 5111-5121, 2017.

[11] P. O. Carlsson and G. Mattsson, "Oxygen tension and blood flow in relation to revascularization in transplanted adult and fetal rat pancreatic islets," Cell Transplantation, vol. 11, no. 8, pp. 813-820, 2002.

[12] P. O. Carlsson, F. Palm, A. Andersson, and P. Liss, "Markedly decreased oxygen tension in transplanted rat pancreatic islets irrespective of the implantation site," Diabetes, vol. 50, no. 3, pp. 489-495, 2001.
[13] T. M. Suszynski, E. S. Avgoustiniatos, and K. K. Papas, "Intraportal islet oxygenation," Journal of Diabetes Science and Technology, vol. 8, no. 3, pp. 575-580, 2014.

[14] S. S. Mohseni Salehi Monfared, B. Larijani, and M. Abdollahi, "Islet transplantation and antioxidant management: a comprehensive review," World Journal of Gastroenterology, vol. 15, no. 10, pp. 1153-1161, 2009.

[15] L. Piemonti, B. E. Leone, R. Nano et al., "Human pancreatic islets produce and secrete MCP-1/CCL2: relevance in human islet transplantation," Diabetes, vol. 51, no. 1, pp. 55-65, 2002.

[16] T. Itoh, M. Takita, J. A. Sorelle et al., "Correlation of released HMGB1 levels with the degree of islet damage in mice and humans and with the outcomes of islet transplantation in mice," Cell Transplantation, vol. 21, no. 7, pp. 1371-1381, 2012.

[17] Y. X. Li, G. Li, W. P. Dong, D. R. Lu, and J. M. Tan, "Protection of human islets from induction of apoptosis and improved islet function with $\mathrm{HO}-1$ gene transduction," Chinese Medical Journal, vol. 119, no. 19, pp. 1639-1645, 2006.

[18] A. Pileggi, R. D. Molano, T. Berney et al., "Heme oxygenase-1 induction in islet cells results in protection from apoptosis and improved in vivo function after transplantation," Diabetes, vol. 50, no. 9, pp. 1983-1991, 2001.

[19] D. Liuwantara, M. Elliot, M. W. Smith et al., "Nuclear factor$\kappa \mathrm{B}$ regulates $\beta$-cell death: a critical role for $\mathrm{A} 20$ in $\beta$-cell protection," Diabetes, vol. 55, no. 9, pp. 2491-2501, 2006.

[20] S. T. Grey, C. Longo, T. Shukri et al., "Genetic engineering of a suboptimal islet graft with A20 preserves beta cell mass and function," Journal of Immunology, vol. 170, no. 12, pp. 6250-6256, 2003.

[21] S. T. Grey, M. B. Arvelo, W. Hasenkamp, F. H. Bach, and C. Ferran, "A20 inhibits cytokine-induced apoptosis and nuclear factor $\kappa \mathrm{B}$-dependent gene activation in islets," The Journal of Experimental Medicine, vol. 190, no. 8, pp. 11351146, 1999.

[22] D. Ou, X. Wang, D. L. Metzger et al., "Synergistic inhibition of tumor necrosis factor-related apoptosis-inducing ligandinduced apoptosis in human pancreatic beta cells by Bcl-2 and X-linked inhibitor of apoptosis," Human Immunology, vol. 66, no. 3, pp. 274-284, 2005.

[23] J. W. Lee, W. H. Kim, J. Yeo, and M. H. Jung, "ER stress is implicated in mitochondrial dysfunction-induced apoptosis of pancreatic beta cells," Molecules and Cells, vol. 30, no. 6, pp. 545-549, 2010.

[24] A. Srivastava, N. M. Bhatt, T. P. Patel, N. Dadheech, A. Singh, and S. Gupta, "Anti-apoptotic and cytoprotective effect of Enicostemma littorale against oxidative stress in islets of Langerhans," Pharmaceutical Biology, vol. 54, no. 10, pp. 2061-2072, 2016.

[25] A. Bruni, A. R. Pepper, R. L. Pawlick et al., "BMX-001, a novel redox-active metalloporphyrin, improves islet function and engraftment in a murine transplant model," American Journal of Transplantation, vol. 18, no. 8, pp. 1879-1889, 2018.

[26] M. Figliuzzi, B. Bonandrini, S. Silvani, and A. Remuzzi, "Mesenchymal stem cells help pancreatic islet transplantation to control type 1 diabetes," World Journal of Stem Cells, vol. 6, no. 2, pp. 163-172, 2014.

[27] B. W. Lee, M. Lee, H. Y. Chae et al., "Effect of hypoxiainducible VEGF gene expression on revascularization and 
graft function in mouse islet transplantation," Transplant International, vol. 24, no. 3, pp. 307-314, 2011.

[28] A. Golocheikine, V. Tiriveedhi, N. Angaswamy, N. Benshoff, R. Sabarinathan, and T. Mohanakumar, "Cooperative signaling for angiogenesis and neovascularization by VEGF and HGF following islet transplantation," Transplantation, vol. 90, no. 7, pp. 725-731, 2010.

[29] S. S. Uematsu, A. Inagaki, Y. Nakamura et al., "The optimization of the prevascularization procedures for improving subcutaneous islet engraftment," Transplantation, vol. 102, no. 3, pp. 387-395, 2018.

[30] H. Wu, E. S. Avgoustiniatos, L. Swette, S. Bonner-Weir, G. C. Weir, and C. K. Colton, "In situ electrochemical oxygen generation with an immunoisolation device," Annals of the New York Academy of Sciences, vol. 875, no. 1, pp. 105-125, 1999.

[31] K. Bloch, E. Papismedov, K. Yavriyants, M. Vorobeychik, S. Beer, and P. Vardi, "Immobilized microalgal cells as an oxygen supply system for encapsulated pancreatic islets: a feasibility study," Artificial Organs, vol. 30, no. 9, pp. 715-718, 2006.

[32] V. Roth, M. S. Herron, Bueno RA Jr, C. B. Chambers, and M. W. Neumeister, "Stimulating angiogenesis by hyperbaric oxygen in an isolated tissue construct," Undersea \& Hyperbaric Medicine, vol. 38, no. 6, pp. 509-514, 2011.

[33] N. Sakata, N. K. Chan, R. P. Ostrowski et al., "Hyperbaric oxygen therapy improves early posttransplant islet function," Pediatric Diabetes, vol. 11, no. 7, pp. 471-478, 2010.

[34] G. Miao, R. P. Ostrowski, J. Mace et al., "Dynamic production of hypoxia-inducible factor-1alpha in early transplanted islets," American Journal of Transplantation, vol. 6, no. 11, pp. 2636-2643, 2006.

[35] J. H. Juang, B. R. S. Hsu, C. H. Kuo, and S. W. N. Ueng, "Beneficial effects of hyperbaric oxygen therapy on islet transplantation," Cell Transplantation, vol. 11, no. 2, pp. 95-101, 2002.

[36] E. J. Estrada, F. Valacchi, E. Nicora et al., "Combined treatment of intrapancreatic autologous bone marrow stem cells and hyperbaric oxygen in type 2 diabetes mellitus," Cell Transplantation, vol. 17, no. 12, pp. 1295-1304, 2008.

[37] V. Delaune, T. Berney, S. Lacotte, and C. Toso, "Intraportal islet transplantation: the impact of the liver microenvironment," Transplant International, vol. 30, no. 3, pp. 227-238, 2017.

[38] W. Bennet, B. Sundberg, C. G. Groth et al., "Incompatibility between human blood and isolated islets of Langerhans: a finding with implications for clinical intraportal islet transplantation?," Diabetes, vol. 48, no. 10, pp. 1907-1914, 1999.

[39] B. Nilsson, K. N. Ekdahl, and O. Korsgren, "Control of instant blood-mediated inflammatory reaction to improve islets of Langerhans engraftment," Current Opinion in Organ Transplantation, vol. 16, no. 6, pp. 620-6, 2011.

[40] M. A. Kanak, M. Takita, F. Kunnathodi, M. C. Lawrence, M. F. Levy, and B. Naziruddin, "Inflammatory response in islet transplantation," International Journal of Endocrinology, vol. 2014, Article ID 451035, 13 pages, 2014.

[41] L. Moberg, O. Korsgren, and B. Nilsson, "Neutrophilic granulocytes are the predominant cell type infiltrating pancreatic islets in contact with ABO-compatible blood," Clinical and Experimental Immunology, vol. 142, no. 1, pp. 125-131, 2005.
[42] L. Moberg, "The role of the innate immunity in islet transplantation," Upsala Journal of Medical Sciences, vol. 110, no. 1, pp. 17-56, 2009.

[43] N. R. Barshes, S. Wyllie, and J. A. Goss, "Inflammationmediated dysfunction and apoptosis in pancreatic islet transplantation: implications for intrahepatic grafts," Journal of Leukocyte Biology, vol. 77, no. 5, pp. 587-597, 2005.

[44] N. Kirchhof, S. Shibata, M. Wijkstrom et al., "Reversal of diabetes in non-immunosuppressed rhesus macaques by intraportal porcine islet xenografts precedes acute cellular rejection," Xenotransplantation, vol. 11, no. 5, pp. 396-407, 2004.

[45] L. Badet, T. Titus, E. Metzen et al., "The interaction between primate blood and mouse islets induces accelerated clotting with islet destruction," Xenotransplantation, vol. 9, no. 2, pp. 91-96, 2002.

[46] L. Moberg, A. Olsson, C. Berne et al., "Nicotinamide inhibits tissue factor expression in isolated human pancreatic islets: implications for clinical islet transplantation," Transplantation, vol. 76, no. 9, pp. 1285-1288, 2003.

[47] A. Rabinovitch, W. Suarez-Pinzon, K. Strynadka et al., "Transfection of human pancreatic islets with an antiapoptotic gene (bcl-2) protects beta-cells from cytokineinduced destruction," Diabetes, vol. 48, no. 6, pp. 1223-1229, 1999.

[48] B. Ekser and D. K. Cooper, "Overcoming the barriers to xenotransplantation: prospects for the future," Expert Review of Clinical Immunology, vol. 6, no. 2, pp. 219-230, 2014.

[49] A. Koh, P. Senior, A. Salam et al., "Insulin-heparin infusions peritransplant substantially improve single-donor clinical islet transplant success," Transplantation, vol. 89, no. 4, pp. 465-471, 2010.

[50] M. McCall and A. M. Shapiro, "Update on islet transplantation," Cold Spring Harbor Perspectives in Medicine, vol. 2, no. 7, article a007823, 2012.

[51] H. Johansson, M. Goto, D. Dufrane et al., "Low molecular weight dextran sulfate: a strong candidate drug to block IBMIR in clinical islet transplantation," American Journal of Transplantation, vol. 6, no. 2, pp. 305-312, 2006.

[52] B. Gala-Lopez, A. R. Pepper, and A. M. J. Shapiro, "Biologic agents in islet transplantation," Current Diabetes Reports, vol. 13, no. 5, pp. 713-722, 2013.

[53] A. Citro, E. Cantarelli, P. Maffi et al., "CXCR1/2 inhibition enhances pancreatic islet survival after transplantation," The Journal of Clinical Investigation, vol. 122, no. 10, pp. 36473651, 2012.

[54] J. Wang, Z. Sun, W. Gou et al., " $\alpha$-1 antitrypsin enhances islet engraftment by suppression of instant blood-mediated inflammatory reaction," Diabetes, vol. 66, no. 4, pp. 970980, 2017.

[55] S. Cabric, J. Sanchez, T. Lundgren et al., "Islet surface heparinization prevents the instant blood-mediated inflammatory reaction in islet transplantation," Diabetes, vol. 56, no. 8 , pp. 2008-2015, 2007.

[56] Y. Teramura and H. Iwata, "Improvement of graft survival by surface modification with poly (ethylene glycol)-lipid and urokinase in intraportal islet transplantation," Transplantation, vol. 91, no. 3, pp. 271-278, 2011.

[57] H. Chen, Y. Teramura, and H. Iwata, "Co-immobilization of urokinase and thrombomodulin on islet surfaces by poly 
(ethylene glycol)-conjugated phospholipid," Journal of Controlled Release, vol. 150, no. 2, pp. 229-234, 2011.

[58] N. M. Luan, Y. Teramura, and H. Iwata, "Immobilization of soluble complement receptor 1 on islets," Biomaterials, vol. 32, no. 20, pp. 4539-4545, 2011.

[59] U. Johansson, G. Elgue, B. Nilsson, and O. Korsgren, "Composite islet-endothelial cell grafts: a novel approach to counteract innate immunity in islet transplantation," American Journal of Transplantation, vol. 5, no. 11, pp. 2632-2639, 2005.

[60] D. E. Sutherland, R. Sibley, X. Z. Xu et al., "Twin-to-twin pancreas transplantation: reversal and reenactment of the pathogenesis of type I diabetes," Transactions of the Association of American Physicians, vol. 97, pp. 80-87, 1984.

[61] J. W. Yoon and H. S. Jun, "Autoimmune destruction of pancreatic beta cells," American Journal of Therapeutics, vol. 12, no. 6, pp. 580-591, 2005.

[62] C. F. Verge, R. Gianani, E. Kawasaki et al., "Prediction of type I diabetes in first-degree relatives using a combination of insulin, GAD, and ICA512bdc/IA-2 autoantibodies," Diabetes, vol. 45, no. 7, pp. 926-933, 1996.

[63] L. Piemonti, M. J. Everly, P. Maffi et al., "Alloantibody and autoantibody monitoring predicts islet transplantation outcome in human type 1 diabetes," Diabetes, vol. 62 , no. 5, pp. 1656-1664, 2013.

[64] R. Hilbrands, V. A. L. Huurman, P. Gillard et al., “Differences in baseline lymphocyte counts and autoreactivity are associated with differences in outcome of islet cell transplantation in type 1 diabetic patients," Diabetes, vol. 58, no. 10, pp. 2267-2276, 2009.

[65] C. Jaeger, M. D. Brendel, B. J. Hering, M. Eckhard, and R. G. Bretzel, "Progressive islet graft failure occurs significantly earlier in autoantibody-positive than in autoantibodynegative IDDM recipients of intrahepatic islet allografts," Diabetes, vol. 46, no. 11, pp. 1907-1910, 1997.

[66] S. Reffet and C. Thivolet, "Immunology of pancreatic islet transplantation," Diabetes \& Metabolism, vol. 32, no. 5, pp. 523-526, 2006.

[67] C. Enderby and C. A. Keller, "An overview of immunosuppression in solid organ transplantation," The American Journal of Managed Care, vol. 21, 1 Supplement, pp. s12-s23, 2015.

[68] B. J. Olack, C. J. Swanson, K. S. Flavin et al., "Sensitization to HLA antigens in islet recipients with failing transplants," Transplantation Proceedings, vol. 29, no. 4, pp. 2268-2269, 1997.

[69] P. M. Campbell, A. Salam, E. A. Ryan et al., "Pretransplant HLA antibodies are associated with reduced graft survival after clinical islet transplantation," American Journal of Transplantation, vol. 7, no. 5, pp. 1242-1248, 2007.

[70] R. Cardani, A. Pileggi, C. Ricordi et al., "Allosensitization of islet allograft recipients," Transplantation, vol. 84, no. 11, pp. 1413-1427, 2007.

[71] E. Pouliquen, P. Baltzinger, A. Lemle et al., “Anti-donor HLA antibody response after pancreatic islet grafting: characteristics, risk factors, and impact on graft function," American Journal of Transplantation, vol. 17, no. 2, pp. 462-473, 2017.

[72] M. Kimelman and G. Brandacher, "Trends in immunosuppression after pancreas transplantation: what is in the pipeline?," Current Opinion in Organ Transplantation, vol. 18, no. 1, pp. 76-82, 2013.
[73] S. A. Nanji, W. W. Hancock, B. Luo et al., "Costimulation blockade of both inducible costimulator and CD40 ligand induces dominant tolerance to islet allografts and prevents spontaneous autoimmune diabetes in the NOD mouse," Diabetes, vol. 55, no. 1, pp. 27-33, 2006.

[74] M. R. Nicolls, M. Coulombe, J. Beilke, H. C. Gelhaus, and R. G. Gill, "CD4-dependent generation of dominant transplantation tolerance induced by simultaneous perturbation of CD154 and LFA-1 pathways," Journal of Immunology, vol. 169, no. 9, pp. 4831-9, 2002.

[75] A. B. Adams, N. Shirasugi, T. R. Jones et al., "Development of a chimeric anti-CD40 monoclonal antibody that synergizes with LEA29Y to prolong islet allograft survival," Journal of Immunology, vol. 174, no. 1, pp. 542-550, 2005.

[76] T. Aoyagi, K. Yamashita, T. Suzuki et al., "A human antiCD40 monoclonal antibody, 4D11, for kidney transplantation in cynomolgus monkeys: induction and maintenance therapy," American Journal of Transplantation, vol. 9, no. 8, pp. 1732-1741, 2009.

[77] I. R. Badell, M. C. Russell, K. Cardona et al., "CTLA4Ig prevents alloantibody formation following nonhuman primate islet transplantation using the CD40-specific antibody 3A8," American Journal of Transplantation, vol. 12, no. 7, pp. 1918-1923, 2012.

[78] M. Lowe, I. R. Badell, P. Thompson et al., "A novel monoclonal antibody to CD40 prolongs islet allograft survival," American Journal of Transplantation, vol. 12, no. 8, pp. 2079-2087, 2012.

[79] E. S. Yolcu, H. Zhao, L. Bandura-Morgan et al., "Pancreatic islets engineered with SA-FasL protein establish robust localized tolerance by inducing regulatory T cells in mice," Journal of Immunology, vol. 187, no. 11, pp. 5901-5909, 2011.

[80] S. M. Kang, D. B. Schneider, Z. Lin et al., "Fas ligand expression in islets of Langerhans does not confer immune privilege and instead targets them for rapid destruction," Nature Medicine, vol. 3, no. 7, pp. 738-743, 1997.

[81] H. T. Lau and C. J. Stoeckert, "Fas L-too much of a good thing? Transplanted grafts of pancreatic islet cells engineered to express Fas ligand are destroyed not protected by the immune system," Nature Medicine, vol. 3, no. 7, pp. 727-728, 1997.

[82] D. G. Silva, N. Petrovsky, L. Socha, R. Slattery, P. Gatenby, and B. Charlton, "Mechanisms of accelerated immunemediated diabetes resulting from islet beta cell expression of a Fas ligand transgene," Journal of Immunology, vol. 170, no. 10, pp. 4996-5002, 2003.

[83] D. R. Green and C. F. Ware, "Fas-ligand: privilege and peril," Proceedings of the National Academy of Sciences of the United States of America, vol. 94, no. 12, pp. 5986-5990, 1997.

[84] M. M. El Khatib, T. Sakuma, J. M. Tonne et al., “ $\beta$-Celltargeted blockage of PD1 and CTLA4 pathways prevents development of autoimmune diabetes and acute allogeneic islets rejection," Gene Therapy, vol. 22, no. 5, pp. 430-438, 2015.

[85] R. D. Molano, A. Pileggi, T. Berney et al., "Long-term islet allograft survival in nonobese diabetic mice treated with tacrolimus, rapamycin, and anti-interleukin-2 antibody," Transplantation, vol. 75, no. 11, pp. 1812-1819, 2003.

[86] J. M. M. Granados, G. Benichou, and T. Kawai, "Hematopoietic stem cell infusion/transplantation for induction of allograft tolerance," Current Opinion in Organ Transplantation, vol. 20, no. 1, pp. 49-56, 2015. 
[87] Q. Tang, J. A. Bluestone, and S. M. Kang, "CD4(+)Foxp3(+) regulatory $\mathrm{T}$ cell therapy in transplantation," Journal of Molecular Cell Biology, vol. 4, no. 1, pp. 11-21, 2012.

[88] J. A. Hayward, C. E. Ellis, K. Seeberger et al., "Cotransplantation of mesenchymal stem cells with neonatal porcine islets improve graft function in diabetic mice," Diabetes, vol. 66, no. 5, pp. 1312-1321, 2017.

[89] M. Koulmanda, R. N. Smith, A. Qipo, G. Weir, H. Auchincloss, and T. B. Strom, "Prolonged survival of allogeneic islets in cynomolgus monkeys after short-term antiCD154-based therapy: nonimmunologic graft failure?," American Journal of Transplantation, vol. 6, no. 4, pp. 687696, 2006.

[90] E. A. Ryan, B. W. Paty, P. A. Senior et al., "Five-year followup after clinical islet transplantation," Diabetes, vol. 54, no. 7, pp. 2060-2069, 2005.

[91] D. C. Wahoff, B. E. Papalois, J. S. Najarian et al., “Autologous islet transplantation to prevent diabetes after pancreatic resection," Annals of Surgery, vol. 222, no. 4, pp. 562-579, 1995.

[92] N. Montero and J. Pascual, "Immunosuppression and posttransplant hyperglycemia," Current Diabetes Reviews, vol. 11, no. 3, pp. 144-154, 2015.

[93] E. B. Rangel, "Tacrolimus in pancreas transplant: a focus on toxicity, diabetogenic effect and drug-drug interactions," Expert Opinion on Drug Metabolism \& Toxicology, vol. 10, no. 11, pp. 1585-1605, 2014.

[94] M. Bugliani, M. Masini, R. Liechti et al., "The direct effects of tacrolimus and cyclosporin A on isolated human islets: a functional, survival and gene expression study," Islets, vol. 1, no. 2, pp. 106-110, 2009.

[95] R. Gao, J. Ustinov, O. Korsgren, and T. Otonkoski, "Effects of immunosuppressive drugs on in vitro neogenesis of human islets: mycophenolate mofetil inhibits the proliferation of ductal cells," American Journal of Transplantation, vol. 7, no. 4, pp. 1021-1026, 2007.

[96] J. D. Johnson, Z. Ao, P. Ao et al., "Different effects of FK506, rapamycin, and mycophenolate mofetil on glucosestimulated insulin release and apoptosis in human islets," Cell Transplantation, vol. 18, no. 8, pp. 833-845, 2009.

[97] N. E. Davis, D. Hamilton, and M. J. Fontaine, "Harnessing the immunomodulatory and tissue repair properties of mesenchymal stem cells to restore $\beta$ cell function," Current Diabetes Reports, vol. 12, no. 5, pp. 612-622, 2012.

[98] E. Estil les, N. Téllez, J. Escoriza, and E. Montanya, "Increased $\beta$-cell replication and $\beta$-cell mass regeneration in syngeneically transplanted rat islets overexpressing insulin-like growth factor II," Cell Transplantation, vol. 21, no. 10, pp. 2119-2129, 2012.

[99] R. B. Jalili, A. Moeen Rezakhanlou, A. Hosseini-Tabatabaei, Z. Ao, G. L. Warnock, and A. Ghahary, "Fibroblast populated collagen matrix promotes islet survival and reduces the number of islets required for diabetes reversal," Journal of Cellular Physiology, vol. 226, no. 7, pp. 1813-1819, 2011.

[100] V. Ruan, L. S. C. Czer, M. Awad et al., "Use of anti-thymocyte globulin for induction therapy in cardiac transplantation: a review," Transplantation Proceedings, vol. 49, no. 2, pp. 253-259, 2017.

[101] B. J. Hering, R. Kandaswamy, J. V. Harmon et al., "Transplantation of cultured islets from two-layer preserved pancreases in type 1 diabetes with anti-CD3 antibody," American Journal of Transplantation, vol. 4, no. 3, pp. 390-401, 2004.

[102] M. F. Nijhoff, M. A. Engelse, J. Dubbeld et al., "Glycemic stability through islet-after-kidney transplantation using an alemtuzumab-based induction regimen and long-term triple-maintenance immunosuppression," American Journal of Transplantation, vol. 16, no. 1, pp. 246-253, 2016.

[103] M. Campara, I. G. Tzvetanov, and J. Oberholzer, "Interleukin-2 receptor blockade with humanized monoclonal antibody for solid organ transplantation," Expert Opinion on Biological Therapy, vol. 10, no. 6, pp. 959-969, 2010.

[104] A. M. J. Shapiro, J. R. T. Lakey, E. A. Ryan et al., "Islet transplantation in seven patients with type 1 diabetes mellitus using a glucocorticoid-free immunosuppressive regimen," New England Journal of Medicine, vol. 343, no. 4, pp. 230238, 2000.

[105] M. Nagata, Y. Mullen, S. Matsuo, and K. Miyazawa, "Fetal islet but not kidney allografts are rejected in miniature swine treated with cyclosporine and azathioprine," Transplantation Proceedings, vol. 21, 1 Part 3, pp. 2661-2662, 1989.

[106] M. D. Bellin, R. Kandaswamy, J. Parkey et al., "Prolonged insulin independence after islet allotransplants in recipients with type 1 diabetes," American Journal of Transplantation, vol. 8, no. 11, pp. 2463-2470, 2008.

[107] T. Froud, D. A. Baidal, G. Ponte, J. V. Ferreira, C. Ricordi, and R. Alejandro, "Resolution of neurotoxicity and $\beta$-cell toxicity in an islet transplant recipient following substitution of tacrolimus with MMF," Cell Transplantation, vol. 15, no. 7, pp. 613-620, 2006.

[108] C. T. Bussiere, J. R. T. Lakey, A. M. J. Shapiro, and G. S. Korbutt, "The impact of the mTOR inhibitor sirolimus on the proliferation and function of pancreatic islets and ductal cells," Diabetologia, vol. 49, no. 10, pp. 2341-2349, 2006.

[109] G. Mai, P. Bucher, P. Morel et al., "Anti-CD154 mAb treatment but not recipient CD154 deficiency leads to long-term survival of xenogeneic islet grafts," American Journal of Transplantation, vol. 5, no. 5, pp. 1021-1031, 2005.

[110] A. M. Posselt, G. L. Szot, L. A. Frassetto et al., "Islet transplantation in type 1 diabetic patients using calcineurin inhibitorfree immunosuppressive protocols based on T-cell adhesion or costimulation blockade," Transplantation, vol. 90, no. 12, pp. 1595-1601, 2010.

[111] C. P. Larsen, T. C. Pearson, A. B. Adams et al., "Rational development of LEA29Y (belatacept), a high-affinity variant of CTLA4-Ig with potent immunosuppressive properties," American Journal of Transplantation, vol. 5, no. 3, pp. 443453, 2005.

[112] L. Zhang, Z. Qi, D. Wu, S. Shan, and H. Ekberg, “Additive effects of leflunomide and tacrolimus in prevention of islet xenograft rejection," Scandinavian Journal of Immunology, vol. 59, no. 3, pp. 255-260, 2004.

[113] B. Rao, S. M. Jafri, M. Kazimi, K. Mullins, M. Raoufi, and M. C. Segovia, "A case report of acute cellular rejection following intestinal transplantation managed with adalimumab," Transplantation Proceedings, vol. 48, no. 2, pp. 536538, 2016.

[114] A. Bagul, "Ischaemic/reperfusion injury: role of infliximab," World Journal of Transplantation, vol. 2, no. 3, pp. 35-40, 2012. 
[115] S. M. Jin, W. Shim, B. J. Oh et al., "Anakinra protects against serum deprivation-induced inflammation and functional derangement in islets isolated from nonhuman primates," American Journal of Transplantation, vol. 17, no. 2, pp. 365-376, 2017.

[116] S. M. Jin, K. S. Kim, S. Y. Lee et al., "The sequential combination of a JNK inhibitor and simvastatin protects porcine islets from peritransplant apoptosis and inflammation," Cell Transplantation, vol. 20, no. 7, pp. 1139-1151, 2011. 


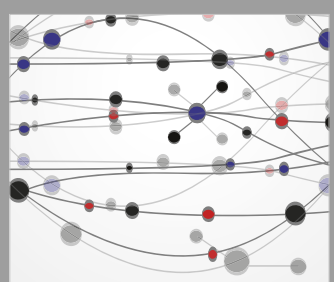

The Scientific World Journal
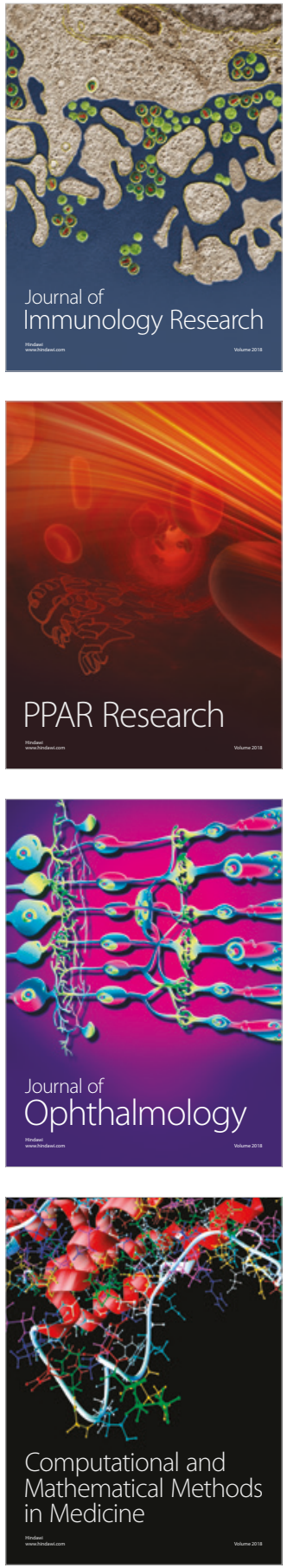

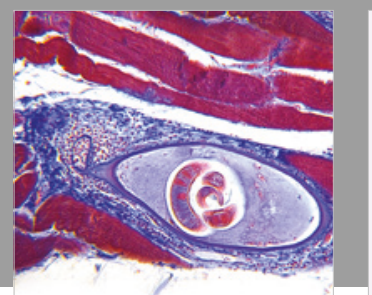

Gastroenterology Research and Practice

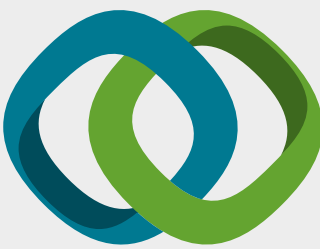

\section{Hindawi}

Submit your manuscripts at

www.hindawi.com
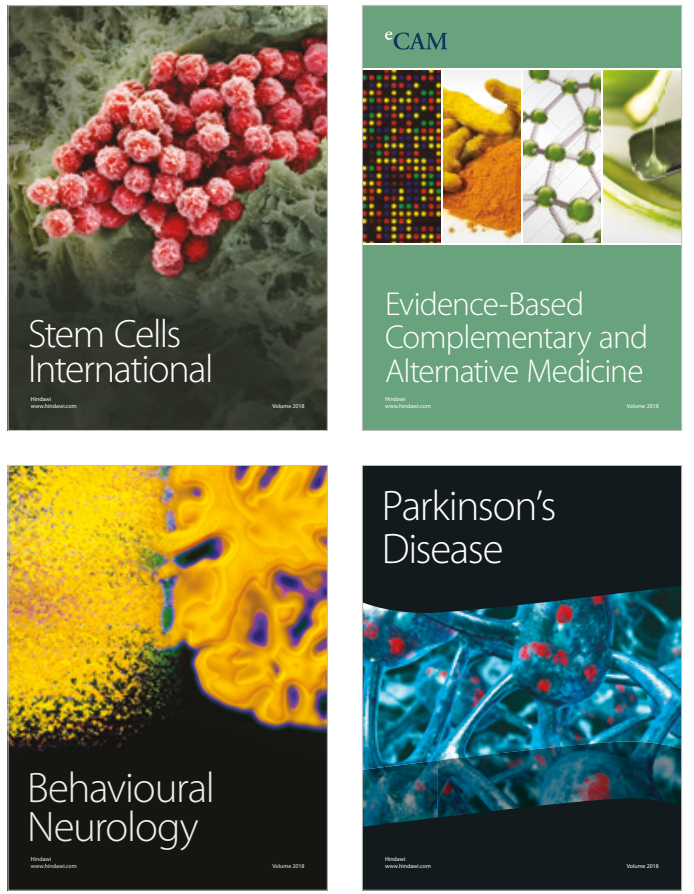

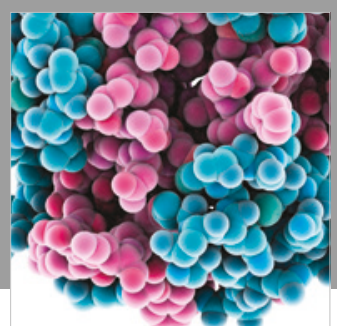

ournal of

Diabetes Research

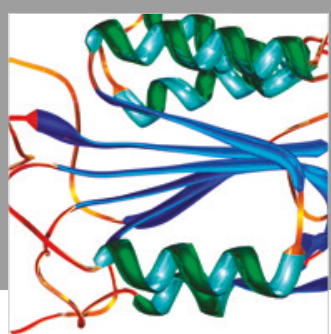

Disease Markers
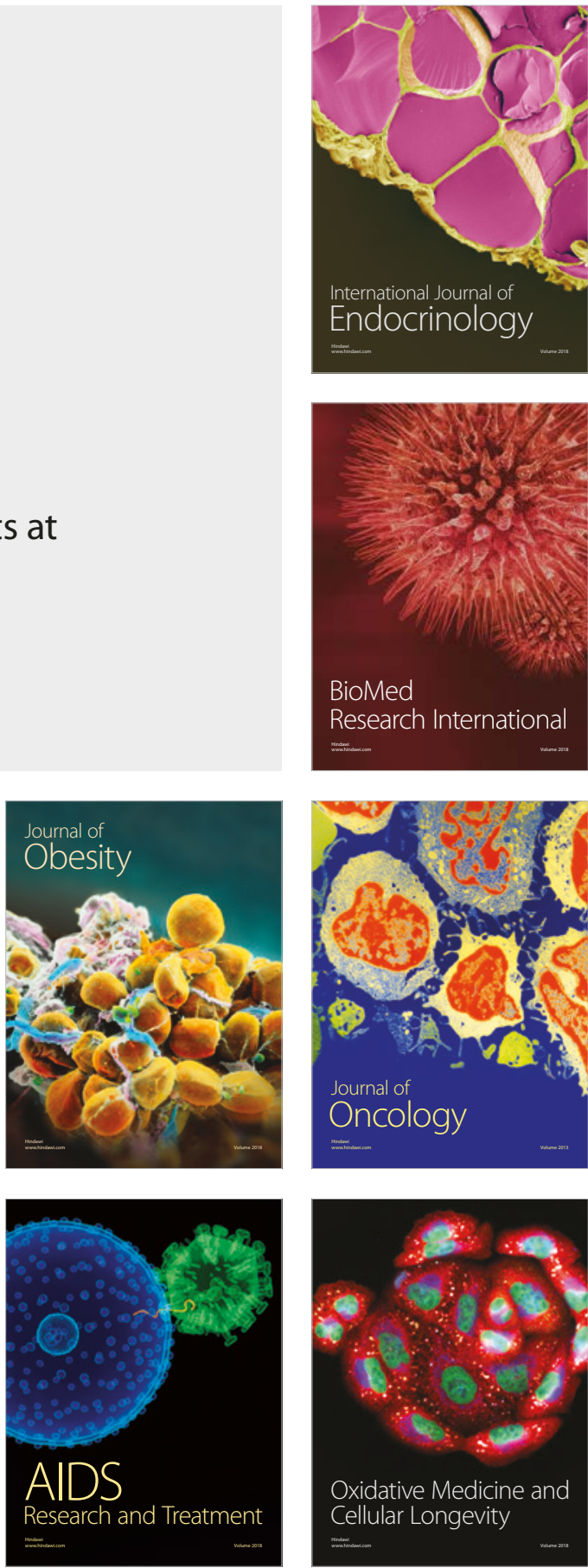